\title{
THE IMPORTANCE OF THE CONCEPT OF SUSTAINABLE DEVELOPMENT IN THE FORMULATION OF THE ASSUMPTIONS OF CONTEMPORARY EUROPEAN PUBLIC SECURITY POLICY
}

\author{
Izabela Oleksiewicz \\ Katarzyna Stachurska-Szczesiak \\ Izabela Oleksiewicz \\ Rzeszów University of Technology, \\ Faculty of Management, Department of Banking and Finance \\ e-mail: oleiza@prz.edu.pl \\ Katarzyna Stachurska-Szczesiak \\ Maria Curie-Skłodowska University in Lublin, \\ Faculty of Political Science, Department of International Relations \\ e-mail: katarzyna.stachurska-szczesiak@poczta.umcs.lublin.pl
}

\begin{abstract}
The concept of sustainable development at the level of international discussion was introduced in 1987 by the Brundtland report (Our Common Future). Its appearance can be regarded as a breakthrough in the current thinking about society and nature. In order to achieve sustainable development there is a need to combine three elements: social equality, economic growth and efficiency, and environmental issues, while preserving resources for future generations. In recent discussions on the concept of sustainable development, the Eurocentric attitude has prevailed, as the result of embodiment of this development in the economic strategies of developed and the most socially responsible countries. At the outset, discussion on the concept of self-sustaining development related to the problems of underdeveloped countries in the 1960s and had little in common with the economic and social advancement. Developed countries, thanks to their resources and instruments, can become transmitters of the concept, securing and stabilizing the situation in the countries neighboring the EU. Cooperation within the Mediterranean basin is an example of such a security policy of the EU towards developing countries that are recipients of both resources and knowledge associated with the concept. Mutual cooperation in establishing a framework for the concept is conducive to the common security of the Mediterranean region. The aim of this paper is to analyze the concept of sustainable development in the context of contemporary European security policy and law enforcement objectives given the close neighborhood of Europe and the MENA region as culturally diverse societies.
\end{abstract}

Key words: sustainable development, public order, public security policy, Mediterranean Basin 


\section{THE GENESIS AND THE NOTION OF THE CONCEPT OF "SUSTAINABLE DEVELOPMENT"}

The concept of sustainable development was introduced into international discussion in 1987 by the Brundtland report (Our Common Future). Its appearance can be regarded as a breakthrough in current thinking about society and nature. ${ }^{1}$ It is the result of people recognizing the need for changes in the current development of humanity in the aftermath of alarming forecasts in the 1970s and 1980s about the state of the environment. As defined by the report, the aim of all the international community should be "development that meets the needs of the present generation without compromising the ability of future generations to meet their own needs." In other words - it is an attempt to respond to the needs of the present generation without compromising the ability of future generations to meet their own needs. ${ }^{2}$ For development to be self-sustaining or permanent, it must join together three elements: social equality, economic growth and efficiency, and preservation the environment, for the current and future generations. Such a development is not a static state, but a process of transformation that takes into account social, economic and environmental issues.

During the 1960s, the matter of the environment was of secondary importance The damage caused to nature was not the subject of debate. The positive effects of growth and progress, in both scientific and technical, was put in the foreground. Changes started at the beginning of the 1970s, when there was media coverage of major ecological disasters caused by uncritical economic growth. Debates at that time about the depletion of natural resources created a growing awareness that the current conditions of growth could not continue indefinitely. This wave of reflection had positive effects, which were reflected in the institutionalization of the environment. The first world conference about the environment, held in June 1972 in Stockholm, was a grassroots initiative, organized as a result of pressure from citizens in industrialized countries. The Stockholm Declaration identified 26 principles of sustainable development ${ }^{3}$ which were intended for all governments and people and would be reflected by the development of future multilateral agreements. Unfortunately, political and economic factors caused a large part of the public as well as politicians to no longer focus on protecting the environment Thus, these principles were included in the international legal system.

However, some of the ideas developed in Stockholm were later confirmed in the Report of 1987 and in Rio Conference in 1992. The most important were the words of Maurice Strong (Secretary General of the Stockholm Conference),

1 See: P. Pieczyński, B. Skubiak, Pojęcie ekorozwój, [in:] Ekorozwój i Agenda 21. Interdyscyplinarny model kształcenia, ed. P. Pieczyński, Szczecin 2007, p. 199.

2 Cf. CMED, Commission Mondiale sur l'Environnement et le Développement, „Notre avenir à tous". Rapport G. H. Brundtland, ONU, avril 1987.

3 See:URL < http://www.diplomatie.gouv.fr/fr/sites/odyssee-developpement-durable/files/1/ Declaration_finale_conference_stockholm_1972.pdf $>$ (access: 10.09.2014). 
who stressed the need to consider the needs of the present generation with those of future generations and to integrate environmental issues into development strategies. In this occasion, he formulated the concept of "eco development"4, which was quickly replaced by the UN's nomenclature of sustainable development - called permanent or sustainable development, and for the purpose of this article, self-sustaining development.

The growing importance of the concept of sustainable development took place in the late 1980s and early 1990s and connected again to the emergence of a number of natural and environmental disasters resulting from technological development, e.g. in Chernobyl in 1986. The highlight of growing awareness about the risks of an ecological nature was the Brundtland Report of 1987. It created the basis for the preparation of the UN Conference on Environment and Development (United Nations Conference on Environment and Development UNCED), held in 1992 in Rio de Janeiro. The resulting program, Agenda $21^{5}$, was adopted as a worldwide strategy for the development of self-sustaining, growth which set guidelines for local authorities on how to achieve the objectives of sustainable development. It sought to connect environmental objectives with the satisfaction of social needs and stimulating this process for development. ${ }^{6}$ It was an attempt to reconcile the requirements of development, particularly in poor and developing countries with limitations resulting from environmental protection in both the North and the South. The creation of the term sustainable development is attributed to the Brundtland report. Since then, environmental issues and development have been considered together: on the one hand, because the development process is not indifferent to the environment (resource extraction often results in the release of contaminants), and on the other one because the quality of the environment can affect the ability of development (negative impact of pollution on human health). ${ }^{7}$

Despite strong differences in interpretation, everyone recognizes that the concept includes three main aspects: economic development, environmental protection, and social and human development. The economy is the engine of sustainable development because it allows for the improvement of social conditions, taking into account the limitations imposed by the environment. The interaction of these three elements creates three properties for this concept: justice, dignified life and durability.

${ }^{4}$ I. Sachs, Stratégies de l'ecodéveloppement, Paris 1980, as cited in: J. Gudkowski, Ignacy Sachs jako prekursor koncepcji zrównoważonego rozwoju, [in:] Od koncepcji ekorozwoju do ekonomii zrównoważonego rozwoju po, ed. D. Kiełczewski, Białystok 2009, p. 14.

5 Source: URL <http://sustainabledevelopment.un.org/content/documents/Agenda21.pdf > (access: 10.09. 2014).

6 M. Pietraś, Międzynarodowy reżim zmian klimatu, Toruń 2011, p. 117.

7 A. Aknin, V. Géronimi, P. Schembri, Environnement et développement. Quelques réflexions autor du concept de „développement durable”, [in:] Développement durable?. Doctrines, pratiques, évaluations, ed. J.-Y.Martin, Paris 2002, p. 58. 
In recent discussions on the shape of this concept, the Eurocentric attitude has prevailed, a result of its presence in the economic strategies in the countries considered to be developed in terms of civilization and high society-wide responsibility. Meanwhile, the beginnings of a discussion on the concept of self-sustaining development relate to the problems of underdeveloped countries and come from the 1960s and have little in common with the economic and social advancement. ${ }^{8}$

For example, we can consider the euro Mediterranean area in which the developed states on the northern flank of the Mediterranean Basin can become come the "transmitters" of the concept's assumptions to the developing countries on the southern flank of the Mediterranean Basin which will be the recipients. Mutual cooperation in establishing a framework of the concept's use is conducive to the security of the common area of the Mediterranean Basin.

Thus, from the Rio Conference the need to preserve and improve the environment is no longer seen as a luxury for a few rich countries in the North. It is known as a categorical imperative to ensure the long-term future also for developing countries. In the light of the ongoing discussion the subject of environmental degradation appears not only as a consequence of poorly managed development but as the cause of underdevelopment. ${ }^{9}$ It obligated the international community, and especially policy makers in developed and developing countries to change the approach of policy. ${ }^{10}$ The strategies to implement the concept of a sustainable development are different: the fight against poverty and inequality (which from the point of view of the Mediterranean region is important), the change in the content of growth (more quality than quantity), changing the behavior of entities.

\section{THE CONCEPT OF SECURITY AND PUBLIC ORDER PROTECTION}

In an attempt to find the source of the notion of "security" it should be noted that it comes from two words "without" and "custody" (securitas - sine cura), with "custody" meaning effort and care as well as surrounding someone a safeguard and protection, whereas the prefix "without" indicates the absence of one of these features. Submission of these words means a state in which said protection or care is not needed. The concept of "order" means the existence of a regular system, setting something, order, plan, compliance with the standard, with due status, while the general public means intended for all, referring to the

${ }^{8}$ J. Gudkowski, Ignacy Sachs jako prekursor koncepcji zrównoważonego rozwoju, [in:] Od koncepcji ekorozwoju..., p. 12.

${ }^{9}$ The fight against poverty has become the main point of the Millennium Summit, which took place on 6-8 September 2000. Its "product" was the Millennium Report, which sets out the main challenges emerging at the beginning of the new century.

${ }^{10} \mathrm{G}$. Cruse, La prise en compte de l'environnement comme facteur de développement, „TiersMonde" 1994, vol. 35, no. 137, pp. 151-167. 
general public, to the whole of society. ${ }^{11}$ It should be further emphasized that the concepts of security and public order are inseparably linked with the functioning of the state and protection of its most important interests.

In the most general terms, the concept of security means a condition in which crimes are not committed, especially against the life, health and property, and the concept of the state order in which offences ${ }^{12}$ are not committed. These concepts should be used together because, as is rightly emphasized by legal theorists of criminal justice, their content overlaps in some areas. ${ }^{13}$

Assuming, in turn, a wide understanding of security - not only identifying it with ensuring inviolable duration but also with the guarantee of freedom of development - it can be seen that the understanding also includes the quest for freedom and welfare, taken as the value dependent on security, but at the same time conditioning them. In short, it can be said that security is synonymous with ensuring the implementation of vital interests. However, in the colloquial meaning, security is the most commonly identified with the military sphere, the sphere of political freedom (also in terms of economic policy), and welfare, of course, with the economic sphere. This understanding is popular in public life and, therefore, this analysis refers to it. ${ }^{14}$

The function of the state in protecting public safety and order is traditionally carried out using two aligned forms of legislative action, i.e., setting up and maintaining certain formations designed to protect the security and public order and taking "political" actions in order to protect public safety and order. The basic actions to protect public safety ${ }^{15}$ and order by the legislature include defining the powers of public officers performing public safety and order tasks, refining the shape of the officers of the service relationship, determining the conditions for integration of the police formation in society, adopting the state budget, constructing criminal and penal law and administrative law. ${ }^{16}$

A direct threat is related to the possibility of a war with the state of being. A political, economic, social or cultural and even ecological crisis can also affect the international situation ${ }^{17}$ of the state. The range of relationships with

${ }^{11}$ Spoleczno-moralna potrzeba bezpieczeństwa i porzadku publicznego, ed. J. Świtka, M. Kuć, G. Gozdór, Towarzystwo Naukowe KUL, 2007, pp. 165-166.

${ }^{12}$ Cf. J. Widacki, P. Sarnecki, Ustrój i organizacja Policji w Polsce oraz jej zadania w ochronie bezpieczeństwa i porządku (reforma Policji-część I). Warszawa-Kraków 1997, pp. 7-15.

${ }^{13}$ Cf. L. Falandysz, Pojęcie porzadku publicznego w prawie karnym i karnoadministracyjnym. „Palestra” 1969, no. 2, p. 64; J. Zaborowski, Administracyjno-prawne ujęcie pojęć bezpieczeństwo publiczne i porzadek publiczny; niektóre uwagi w świetle unormowań prawnych 19831984. „Zeszyty Naukowe ASW” 1985, no. 41.

${ }^{14}$ J. Stańczyk, Zmiany systemowe w postsocjalistycznych państwach Europy Środkowej i Wschodniej, Studia Europejskie, 3/1997, p. 37.

${ }^{15}$ Ibidem, p. 78.

${ }^{16}$ Ibidem, pp. 80-86.

${ }^{17}$ A. Kerdoun, La dimension environnementale de la securité dans l'espace méditerranéen, „Les Cahiers de l'Orient” Juillet 2008, no. 91, p. 63. 
its neighbors shapes the potential risks and challenges shaping the security of the state. ${ }^{18}$

The protection of public safety and order were nearly always among the most important objectives of the activity of the public authorities whose primary role is to ensure security for the citizens of the country - within legally defined measures and procedures for their use - is understood as an essential component that is the basis of operation and human development and the different forms of the community. ${ }^{19}$ The keyword for further consideration is that each country's areas of safety, despite activities undertaken by specialized state bodies, may still be subject to various risks, and in order to ensure the normal operation of the unit in the country, each of these areas must be subjected to adequate protection guaranteed a specific competences relevant actors. ${ }^{20}$

Safety must, therefore, be identified not only with ensuring inviolable duration, but also with guaranteeing freedom of development, the pursuance to freedom and welfare taken as the dependent value from security but at the same time conditioning it. It should be further emphasized that the need for freedom and welfare are important components of security and the analysis of security issues should take them into account. ${ }^{21}$

When analyzing the problems of security and public policy of EU member countries and the importance of the concept of "sustainable development" in the conduct of this policy, it should be noted that the safety protection is usually identified with the actions of the military, political and economic spheres. These actions, in turn, can be taken both globally and internally in individual countries. On the other hand, sustainable development is a response to contemporary threats, especially of an ecological nature. Its full application will mean a better quality of life for everyone now and for future generations. It offers a vision of progress that integrates immediate and long-term aims, local activities that must complement each other with global activities for social, economic, but primarily, environmental ones.

${ }^{18}$ W. Gizicki, Polityczne uwarunkowania bezpieczeństwa europejskiego, wyd. Marszałek, Toruń 2008, pp. 197-198.

${ }^{19}$ M. Polinceusz, Ochrona bezpieczeństwa państwa jako przesłanka ograniczeń w korzystaniu z praw i wolności obywatelskich w Unii Europejskiej - wybrane zagadnienia, [in:] Ochrona praw jednostki a bezpieczeństwo państwa, ed. I. Oleksiewicz, M. Pomykała, J. Rajchel, Wyższa Szkoła Oficerska Sił Powietrznych, Dęblin 2012, p. 97.

${ }^{20}$ Cf. J. Rajchel, Sity zbrojne w zarządzaniu kryzysowym, Zeszyty Naukowe Wyższej Szkoły Informatyki, Zarządzania i Administracji w Warszawie 1 (8) 2008, p. 147.

${ }^{21}$ See also: I. Oleksiewcz, M. Polinceusz, Ograniczenie swobód jednostki jako konsekwencje działań podejmowanych $w$ zakresie ochrony bezpieczeństwa i porządku publicznego państwa, [in:] Wybrane problemy przeciwdziałania zagrożeniom bezpieczeństwa publicznego, ed. I. Oleksiewcz, M. Polinceusz, Rzeszów 2012, pp. 13-14. 


\section{THE CONDITIONS OF EU MEMBER COUNTRIES SECURITY POLICY}

Systemic changes in the international environment due to qualitatively new features conditioned by the processes of globalization and trans-nationalism become specific political structures for the possibility of asymmetric threats. This results in the appearance of two processes: the transfer of subjectivity and potential for action in the public sector, controlled by the state, and the private sector which is dominated by transnational actors such as corporations. This means that the transnational mobility of production factors and the structures of global civil society are accompanied by the destruction of transnational mobility measures in the form of the terrorist organizations and the structures of organized crime..$^{22}$

It should be noted that global and local security are determined by many factors, including political ones. Firstly, after the end of the Cold War and the collapse of the bipolar system, the scale, scope and intensity of the traditional military threats (this refers primarily to the transatlantic area) decreased significantly. In contrast, reducing the risk of the outbreak of a world war did not translate into the mitigation of regional and local conflicts. Asymmetric threats simultaneously developed or acquired new forms. The reason for this was a lot of factors that reinforce each other, e.g. the transformation of the international order, new divisions, conflicts and others.

Secondly, the end of the current order meant that a few factors have gained in importance as determinants of the shape of the international security environment, such as terrorism and thus as determinants of the development of the terrorist organizations. And the collapse of the bipolar system meant the USA gained a global position as superpower. ${ }^{23}$

Thirdly, the advantage of the United States over other countries in the level of economic and military-technological advancement is so vast that it will not be quickly narrowed ${ }^{24}$ On the other hand, by obtaining a position of sole superpower, the USA is due to take greater responsibility for the state of international relations, as exemplified by the bilateral agreement with the European Union about the processing and transferring of financial messages for the purpose of tracking terrorists as part of the Finance Tracking Program. As M. Madej points out it rightly, only the United States now has the role of "policeman" in maintaining

${ }^{22}$ M. Pietraś, Transnarodowość zagrożeń asymetrycznych, [in:] Zagrożenia asymetryczne wspótczesnego świata, ed. S. Wojciechowski, R. Fiedler, Wyd. UAM, Poznań 2009, p. 86.

${ }^{23}$ Cf. Z. Brzeziński, O Polsce Europie i Świecie 1988-2001, Bellona, Warszawa 2002, p. 313-315; Bezpieczeństwo międzynarodowe w Europie Środkowej po zimnej wojnie, ed. J. Kukułka, ISM UW, Warszawa 1994, s. 350-363; K. Żukrowska, Globalizacja jako determinanta nowego systemu bezpieczeństwa międzynarodowego, [in:] Globalna gospodarka - lokalne spoleczeństwa. Świat u progu XXI wieku, ed. J. Osiński, KES SGH, Warszawa 2001, pp. 245-262.

${ }^{24}$ Cf. M. Pietraś, Transnarodowość zagrożeń asymetrycznych..., p. 87; M. Madej, Zagrożenie asymetryczne bezpieczeństwa państw obszaru transatlantyckiego, PISM, Warszawa 2007, p. 74, I. Oleksiewicz, Polityka antyterrorystyczna Unii Europejskiej, wyd. UMCS, Lublin 2013, pp. 56-77. 
security in the world, and its situation significantly influences the positioning of its allies, notably the transatlantic area.

Fourthly, with the end of the Cold War the shape the international relations began to gain cultural and civilizationa ${ }^{25}$ diversity It refers primarily to the differences between countries and societies belonging to different cultures and civilizations. ${ }^{26} \mathrm{We}$ cannot forget, herein, about the factor of the migration and what is more that the possibility of refugees' reception in the 1980s decreased, which was connected with increasing the pressure on the movement of people from poorer countries. In many countries, economic stagnation or collapse was accompanied by political instability, social violence and the armed conflicts. More prosperous countries in different parts of the world had to solve an important problem. Throughout the 1980s they were fighting with the growing number of asylum applications. Currently, the number of threats to human rights is growing and changing character. Increasingly, the perpetrators of the most severe violations are non-state actors. We should add to this the fear of terrorism. In each EU country, we have to deal with the big trends of xenophobia ${ }^{27}$, especially in areas where there is a large concentration of refugees and asylum seekers. Although many experiments show that refugees and asylum-seekers may work for the good of the community by motivating others to act, complaints about lowering the level of life in different areas can still be heard.

In the context of the discussion on the division of the international community at the level of civilization and culture we should pay attention to the view expressed by M. Mousseau ${ }^{28}$ who found that the cause of any conflict results from the collision of countries belonging to two different civilizations (market and clientelism) operating on the basis of different principles. Undoubtedly, cultural differences, in particular religion, are the main motive of terrorist groups The growing importance of religion as motivation is widely recognized as the most important change taking place recently in international terrorism. At present it is considered to be the strongest factor threatening the security of the international system because it determines the activities, choice of methods and means and frequency of attacks. ${ }^{29}$ This resulted in terrorists' expansion of the permissible categories of targets and has given the scared character to terrorism. The second

${ }^{25}$ See more: S. P. Huntington, Zderzenie cywilizacji i nowy ksztalt łady światowego, Warszawa 2006; B. Barber, Democracy and terror in the era of jihad vs. Mcworld, [in:] World in collision: terror and the future of global order, ed. K. Booth, T. Dunne, Palgrave Macmillian, New York 2002, pp. 255-262.

${ }^{26}$ A. Porębski, Europejskie mniejszości etniczne. Geneza i kierunki przemian, PWN, Kraków 1991, p. 62.

${ }^{27}$ A good example of this approach is the United Kingdom. In 2001, a young Kurdish refugee was stabbed to death in the city in the north of England what caused a lot of animosity and tension.

${ }^{28}$ M. Mousseau, Market civilization and its clash with terror, "International Security" 2002, vol. 27 , no. 3, pp. 10-30.

${ }^{29}$ See more: A. Cronin, Behind the curve. Globalization and international terrorism, "International Security" 2002, no. 3, pp. 38-40. 
factor causing a growing tendency for terrorists to maximize the escalation of violence and destruction are the constantly increasing technical and organizational possibilities of many active groups that allow them to carry out more and more sophisticated terrorist attacks. ${ }^{30} \mathrm{~A}$ very important role here is played by psychological factor intensified by the media. Media relationship is just as important in the case of a single bombing as in a whole terrorist campaign, thus increasing brutality and violence in the modus operandi of the terrorists. This is one of the best ways to attract the attention of the media and the world.

Fifthly, equally important contemporary divisive factors are the economic and developmental effects of globalization. One needs to mention at this point the general use of information technology and high-speed data transmission resources (computing, telecommunications), or a kind of "specialization" of spheres of production. These processes also result in reducing the importance of traditional industries, reducing the level of employment and determining the need for high specialization of employees. The widespread use of new technologies leads to the transformation of economies. The "second wave" countries try to find "economic niches" allowing them to get rid of the backwardness of civilization. This requires an increase in the level of education and increases unemployment among the uneducated population. For the countries of "third wave" these processes are equivalent to the creation of significant disproportion of development that cause deepening social frustration and increased radicalization and lead to the emergence of new forms of organization of society (mentioned underclass). ${ }^{31}$

Seeing in this way the socio-economic reality of Europe, the major threat to social security should be considered an uneducated population flood from Africa and West Asia. The huge "attractiveness" of Europe is due to socio-economic reasons. The economic potential of the countries in the region, even taking into account the economic boom caused by the Iraq conflict, there are about $200 \%$ lower than in the European Union, and the average growth rate is about 2\% per year.

The rapid population growth in these areas has led to a radical transformation of the demographic structure of the region. According to UN estimations, the percentage of people of working age is about $11.5 \%$ of the total population. And young people under 25 years old has reached $45 \%$ of the overall population. ${ }^{32}$

Europe is, therefore, not an oasis of peace. Its safety is not threatened by any armed conflict that could lead to changes in the external borders of the region. This does not mean that it is a region with a high level of stability. The processes of globalization, particularly their effect on the socio-economic sphere, create new security risks.

${ }^{30}$ B. Nacos, Accomplice or witness? The media role in terrorism, "Current History" 2000, vol. 99 , no. 4 , p. 5 .

${ }^{31}$ Ibidem, p. 7.

${ }^{32}$ Cf. R. Snyder, Hating America: Bin Laden as a civilizational revolutionary, "Review of Politics" 2003, vol. 4, pp. 325-349; M. Madej, op. cit., p. 86. 
They directly affect the internal situation of European countries and the European community. In the opinion of large sections of communities, maintaining the security of employment, an adequate number of jobs, appropriate levels of social security, and cultural identity should be a priority task of the state. This translates into activities such as restrictive asylum policy, approval of certain forms of xenophobia in society, informal curtailing of civil and social rights. These actions - sometimes positively perceived by the society - do not solve problems, and even cause an escalation of the processes of social and ethnic alienation. ${ }^{33}$

Migrants rejected by the community are in a natural way radicalized to form extreme criminal or fundamentalist groups. The aim of the interaction becomes a "welfare state" and the community is limiting their access to the expected level of consumption. And the form of interactions are attacks, rapes, or activities of a terrorist nature. For example, they may use the terrorist attacks carried out in Paris in January and Copenhagen in February 2015. ${ }^{34}$

The processes of globalization have a greater impact on the security environment than the divisions in the international community. ${ }^{35}$ Globalization processes are also considered to be irreversible. Globalization seems to be so advanced that the network of connections between the various countries and societies in the world are too dense to be disintegrated or reduced. An inevitable consequence of globalization is the transformation (erosion) of the sovereignty of states, which affects each of the countries, although in different degrees. This is due to the social processes of de-territorialization and deepening interdependence in every area of social life. This process takes place gradually, but is as durable as globalization itself, thus affecting order and international environment. This creates a wider field for the actions by state subjects and possibilities to create new forms and types of activity, as well as an opportunity for the extension of the existing structure.

It can be concluded that the nature of the state's role in ensuring public safety and order has not changed for centuries. It should be noted that in many countries around the world there is today a tendency for citizens to organize themselves, creating a variety of activities for groups and individuals - activities which are not in conflict with the interests of the state. These actions are related to the sphere of security and public order. It should be keep in mind that a state will never be able to provide its citizens with complete safety, and there is scope for actions by the citizens themselves. ${ }^{36}$ At the present time there is also the danger of violations by law enforcement agencies, in particular the special services, of the rights of suspects in criminal cases, something especially dangerous to the interests of the state. ${ }^{37}$

${ }^{33}$ More on this issue see: M. Madej, op.cit., pp. 44-52.

${ }^{34}$ Terroryzm, source: URL <http://www.rp.pl/temat/9189.html> (access: 17.02.2015).

${ }^{35}$ M. Pietraś, op. cit., p. 82.

${ }^{36}$ Społeczno-moralna potrzeba bezpieczeństwa..., pp. 168-174.

${ }^{37}$ This is shown in German literature. B. Schünemann uses the example of the American prisoners of war in Guantanamo, treated not as suspicious, but as the objects of proceeding. His warning against following the democratic system "road to Guantanamo" ("Warnung vor dem Weg 
Europe in the twenty first century still faces threats to its security. In this area we will never reach a sufficient certainty. Every new step in world development brings new opportunities as much as risk factors. The Union must take effective action to ensure the safety of its Member States. There is a need for constructive cooperation with the regions bordering the EU. The Union must also protect its military and strategic interests by working with allied countries in NATO, and by developing a genuine common security and defense policy. Internal and external security are two sides of the same coin. In other words, Europe also has to fight terrorism and organized crime, which requires closer cooperation between the police forces of the Member States. One of the new challenges was to create a European area of freedom, security and justice, where everyone has equal access to justice and is equally protected by law.

European citizens have the right to live in freedom anywhere in the European Union, without fear of persecution or violence. International crime and terrorism are now the threats that most concern Europeans. The time has come for swift joint action at the European level. EU integration in this field was not provided for at the time of establishment of the European Economic Community. Decision-makers of the EU's Common Foreign and Security Policy will not be denied the efforts in many areas of international activity. When reviewing the activities undertaken within the framework of the Union's security policy, there is a clearly visible desire for its active involvement in the solution to the most important issues and contemporary challenges.

It should be noted that an essential element of the proper operation of all those involved in ensuring safety is the knowledge of the subject. However, much remains to be done, both in terms of the creation and standardization of rules, as well as adapting to the needs of the tasks and the possibility of effective internal security. The future of the European Union's counter-terrorist policy depends not so much on the efficiency of the police and military formations as in the ability to resolve social and international conflicts. ${ }^{38}$ Most of the instruments and competences in the fight against terrorism remain the responsibility of the Member States of the EU, which too often "jealously" guard their sovereign prerogatives and information systems instead of sharing them with confidence and efficiency to protect their citizens.

International organizations remain one of the main instruments of counter-terrorism policy. However, they face a need to adapt to the rapidly changing

nach Guantanamo") has become the main slogan of the discussion panel 26th of Congress Defenders in March 2002. in Mainz, dedicated to the reform of criminal procedure in Germany - see B. Schünemann, Warnung vor Holzwegen der Strafprozessreformen, [in:] Sicherheit durch Strafe?. Öffentlicher Strafanspruch zwischen Legalitätsprinzip und Opferinteresse. 26. Strafverteidigertag, Mainz 8.-10. März 2002, Berlin 2003, p. 267. Quoted after C. Kulesza, Prawo do obrony formalnej a zasada prawdy obiektywnej, [in:] Zasada prawdy materialnej, ed. Z. Sobolewski, G. Artymiak Zakamycze 2006, p. 63.

${ }^{38}$ See M. Marcinko, Współczesne oblicza międzynarodowego terroryzmu, „Pro Memoria” Biuletyn Informacyjny Państwowego Muzeum Auschwitz-Birkenau Nr 22, styczeń 2005. 
security environment. Although the European Union wants to be an important strategic player in the field of counter-terrorism policy, it has adapted relatively slowly and less consequentially, as can be seen on the present example actions against Russia. ${ }^{39}$

\section{THE EFFECTS OF THE EU SECURITY POLICY ON THE EXAMPLE OF THE MEDITERRANEAN BASIN}

The failure of the Barcelona Process and the French EU initiative on the Mediterranean have brought "Mediterranean issues" to the agenda first at the French national level and then at the EU level. The Barcelona Process, which was to be the strengthening of the European Neighborhood Policy - ENP, failed to reduce the differences in the development of two edges, or to resist the negative effects of the conflict in the Middle East and international terrorism. Moreover, there were more and more visible demarcation lines between the shores of the Mediterranean (referring to environmental threats), which represent a potential threat in the future. Hence a need for the introduction of a comprehensive reform of Mediterranean policy arose, perhaps in the context of a project by N. Sarkozy that seemed reasonable enough that he could get interested enough and then take the discussions with the political people in government and then to the EU level.

For the first time the idea of the establishment of a Union for the Mediterranean (UfM), then the Mediterranean Union, was heard in the middle of Sarkozy's campaign speech in February 2007 in Toulon. This idea became real only a few months later as a result of many official and unofficial discussions with top leaders of European countries (e.g. Germany and Spain) as well as the Mediterranean countries (e.g. The Maghreb countries) which are not members of the European Union. During these meetings, it was emphasized how much the form of this project requires in-depth explanations, so as not to multiply existing dialogues, partnerships, and policies (parallel with the Barcelona process of regional cooperation and the ENP, which puts the main focus on bilateral Action Plans). In the course of these discussions the failure of the Barcelona Process and the numerous attempts to resume it was acknowledged, which would result in the emergence of appropriate political formula to constitute a guarantee of stability and security. During the Meeting of States in Brussels on 13-14 March 2008 the Union supported the initiative, changing the name to the "Barcelona Process: Union for the Mediterranean". Officially, the new formula was published in Paris on 13 July $2008 .{ }^{40}$

${ }^{39}$ Cf. E. MacMahon Jr., Terrorism and Human Rights: a Defence Layer's Perspective, "Terrorism and Political Violence" 2002, Vol. 17, Issue 1\&2, pp. 125-129.

${ }^{40}$ Source URL < http://www.diplomatie.gouv.fr/fr/IMG/pdf/Declaration_commune UPM_bis.pdf >; <http://www.emwis.org/initiatives/mediterranean-union/articles/barcelona-process-union-mediterranean-joint $>$ (access: 10.09.2014). 
The Union for the Mediterranean created and strengthened a new space for cooperation between all the countries in this geographical area. It can be specified that for 20 years the Mediterranean Sea has become in the eyes of political and economical elites " the needed project". It seems that self-sustaining development has a privileged position among planning ways of progress. In this aim the Union for the Mediterranean is emphasizing the accent of regional policy cooperation. From the beginning it was based on the principle of developing common solutions. In this framework specific projects arise and are realized, therefore often in the literature it is called a "the union of projects". This fact makes the UfM appear to be (compared with earlier stages of the EU's Mediterranean policy) a very effective political formula, implementing the principles of the concept of sustainable development. In the framework of this cooperation two principles are realized: variable geometry, a flexible and pragmatic approach that allows for the participation of each Mediterranean partner in the implementation of projects affecting its interests, and co-ownership: co-decision and responsibility. ${ }^{41}$ It is intended to go beyond the existing processes and to strengthen relations between its members through the development of new projects at the regional level. The political impulse was supposed to bring not only the "freshness" to Euro-med relations, but also tangible results - and thus to establish equal partnership in the countries bordering the Mediterranean. ${ }^{42}$

Thus, the UfM being "a multilateral branch" of European Neighborhood Policy, seeks to dynamize regional cooperation ${ }^{43}$ and help to increase coherence and maintain security in the Euro-med, paying special attention to the projects aimed at ensuring environmental safety. Cooperation within the UfM takes a strategic dimension, as it combines 43 countries $^{44}$ and 3 continents around the themes and common challenges i.e. social and economic development (creating jobs, supporting businesses); building connections (highways, ports, rail and air) and the self-sustaining development (renewable energy, water, environment, higher education and mobility of young people). An important role in the implementation of such designated areas for action is fulfilled by the UfM Secretariat, established on 4 March 2010 with headquarters in Barcelona. ${ }^{45}$ At the moment, UfM focuses its activities on this area, and project proposals submitted to the Secretariat must

${ }^{41}$ Source: URL <http://ufmsecretariat.org/objectives/> (access: 25.10.2014).

${ }^{42}$ Co-leadership North-South provides that Member States on both sides are treated equally.

${ }^{43}$ In the framework of regional cooperation the aim of UfM is: to enhance regional cooperation, especially in the South-South dimension, to meet the challenges of the economic, social and environmental; to promote the exchange of experience and good practices; to define common strategies for development; to lead to common projects; to encourage in the participation non-governmental actors; to stimulate the development based on the concept of sustainable development.

${ }^{44} \mathrm{UfM}$ is created of 15 countries of South Mediterranean and 28 EU Member States.

${ }^{45}$ Source: URL <http://ufmsecretariat.org/fr/who-we-are/> (access: 25.10.2014). 
respect the principles of sustainable development ${ }^{46}$ : self-sustaining development is one of the priority areas for UfM action, which is reflected in a number of projects. These include inter alia: The Desalination Facility for the Gaza Strip Project, defined for the years 2014-2017 which seeks to deliver 55 million cubic meters of water per year to 1.65 million residents. ${ }^{47}$ One of the most important projects causing high hopes for the future, is the Sunny Plan (The Mediterranean Solar Plan-SMEs).$^{48} \mathrm{MSP}$ is first and foremost an apolitical project, and its purpose is the production of solar energy on an industrial scale; increase the use of renewable energy sources and energy efficiency in the Mediterranean. Therefore, this project provides for the construction by 2020 of additional power production based on solar energy, with a total capacity of $20 \mathrm{GW}$; growth local consumption (region) of electricity generated under the Plan and the export of this energy to the EU to ensure the viability of the project as well as the creation of a legal and institutional framework for the massive development projects in the field of renewable energy sources (e.g. wind). ${ }^{49}$

Partnership for water in the Mediterranean (Global Water Partnership Mediterranean-GWP-Med. $)^{50}$ is a project whose aim is to promote self-sustaining development and management of water resources at all levels in the Mediterranean. One part of the GWP-Med promotes the activities and exchange of knowledge on integrated water resource management (Integrated Water Resources Management - IWRM) to help Mediterranean countries participate in joint planning for water resources and activities at different levels (regional, cross-national local). To achieve this aim, GWP-Med. Plays an intermediary role, a catalyst to facilitate contact between multiple stakeholders (almost 85): authorities, institutions and private companies in the water sector Euro-Mediterranean.

Taking the above into account, these projects cannot be created independently, and the EU Mediterranean policy currently provides the backdrop for many projects aimed at ensuring the safety of (social, economic and environmental) in the common area of the Mediterranean. To succeed all the forces from the actors' zone should join and give the process a common dynamic. ${ }^{51}$ Moreover, joint implementation projects for social development, taking into account the economic

${ }^{46}$ These principles are: to contribute to stability and peace in the whole Mediterranean region; to protect the interests of all members of the UfM; to take into account the principle of variable geometry; to respect the decision of the Member States participating in an ongoing project when it is subject to change.

${ }^{47}$ Source: URL < http://ufmsecretariat.org/the-desalination-facility-for-the-gaza-strip-project/> (access: 20.10 .2014$)$.

${ }^{48}$ Source: URL < http://www.med-impact.fr/en/the-project/mediterranean-solar-plan> (access: 21.10.2014).

${ }^{49}$ See more: URL < http://ec.europa.eu/energy/international/euromed_fr.htm> (access: 21.10. 2014).

${ }^{50}$ Source: URL < http://www.gwp.org/en/GWP-Mediterranean/> (access: 9.10.2014).

${ }^{51}$ See more: S. Chikirou, Entretien avec l'ambassadeur Alain de Roy: L'Union pour la Méditerranée: quoi de neuf?, „Les Cahiers de Orient” 2008, no. 91, pp. 15-16. 
limitations related with environmental protection, can only impact positively on the stabilization of the region.

Although, as written at the beginning, Mediterranean policy of the EC / EU is old and has undergone many stages of development, it still affects the Mediterranean's numerous problems such as hunger, which is often a consequence of drought; pandemics; depletion of natural resources (e.g. water); scarcity of fossil fuels; threats of biodiversity; ecological disasters causing general manifestations of violence and unrest, moreover, which was shown by the Arab Spring in February 2011. These problems seem to arise from the fact that during decades of cooperation, the state focused only on purely commercial and economic relations without taking into account the needs and even the need to maintain and protect the enormous wealth (now endangered) that this region has - the environment. If one believes the report of the Intergovernmental Panel on Climate Change - IPCC / IPCC, the Mediterranean will be particularly affected by global warming. The fight against numerous sources of pollution becomes therefore a priority, because ecological security affects the daily life of the inhabitants (quality of life, health, access to water). Pollution and environmental degradation threaten progress in one of the most important sectors of the economy in the countries of southern flank - tourism. These factors are carriers of a serious risk to regional destabilization caused by the imbalance of ecological, political, demographic. No wonder then that the creators of the UfM realized that the safety of the environment is just as important as energy or civil security.

It should be stressed that the UfM is a well conceived formula reflecting much activity in the implementation of the self-sustaining development principles in common projects, thereby contributing to the stabilization of the southern dimension of the EU. However, the current political situation caused by the Arab Spring, which continues until today and the Israel-Palestinian conflict hinder the realization of its objectives.

\section{CONCLUSIONS}

Order protection and public safety are several of the most important and oldest public tasks and are closely linked to the formation of a public authority. Critical areas for each country may be subjected to security threats of various kinds. Compatibility of protective measures both internally (intra) and externally, usually associated with institutionalized cooperation, frequently requires limitation of individual states or even exclusion of the rights and freedoms of the individual. However, it is important to limit the rights, freedoms and liberties of individuals. Firstly, they have aimed only to enable the use of appropriate instruments to allow Member States affecting the necessary protection of their own interests. Secondly, that meant only the necessary actions and one proportionate to achieving protection of a given interest. 
In conclusion, such an understanding of public security is closely related to the essence of the concept of sustainable development. Both concepts are identified in ensuring the integrity, of course, but also to guarantee the freedom of development, freedom and human well-being While public safety refers mainly to the state, the concept of sustainable development is a global issue and takes into account the different levels of human activity as well as future generations. Development based on the concept of sustainable development perfectly captures the regional dimension of cooperation in the Euro-Mediterranean area. The European Union often declares and emphasizes that the lack of environmental protection, the growing frustration in states and societies of the South resulting from development disparities or insufficient preventive measures in the countries of southern Mediterranean flank, has become an existential threat to the security of the Mediterranean. The response to this growing threat may be the concept of sustainable development. Contemporary development strategies in EU countries that ensure the safety of their citizens should take into account the assumptions of this concept, but not forgetting to bring assistance (both in the transfer of knowledge and financial resources) to the southern flank of Mediterranean states whose unstable internal situation today can destabilize European countries in the future. The establishment of self-sustaining development in the Mediterranean Basin would be a guarantor of public safety, both in terms of socio-economic and ecological safety. The European Union ${ }^{52}$ wishes for such a development not only in Europe but also in the countries bordering it.

\section{ZNACZENIE KONCEPCJI SUSTAINABLE DEVELOPMENT W FORMUŁOWANIU ZAŁOŻEŃ WSPÓŁCZESNEJ EUROPEJSKIEJ POLITYKI BEZPIECZEŃSTWA PUBLICZNEGO}

Streszczenie. Koncepcja sustainable development została wprowadzona na forum międzynarodowe za sprawą raportu Brundtland w 1987 r. (Our Common Future). Jej pojawienie się z pewnością można uznać za przełom w dotychczasowym myśleniu o społeczeństwie i przyrodzie. Aby rozwój był samopodtrzymujący się lub trwały, musi łączyć ze sobą trzy elementy: utrzymywanie równości społecznej przy jednoczesnym wzroście gospodarczym oraz ochrona środowiska naturalnego z uwzględnieniem tak obecnych, jak i przyszłych pokoleń. Rozwój taki nie jest stanem statycznym, lecz procesem transformacji, który uwzględnia warunki społeczne, gospodarcze i środowiskowe. $\mathrm{W}$ dyskusjach nad kształtem koncepcji sustainable developement prowadzonych w ostatnich latach przeważa nastawienie europocentryczne, co jest wynikiem obecności tego rozwoju w strategiach gospodarczych państw uznawanych za rozwinięte pod względem cywilizacyjnym i o wysokiej ogólnospołecznej odpowiedzialności. Tymczasem początki dyskusji nad koncepcją rozwoju samopodtrzymującego się odnoszą się do problematyki państw słabo rozwiniętych. Wywodzą się one z lat 60. i mają niewiele wspólnego z zaawansowaniem społeczno-gospodarczym. Dzięki swoim środkom oraz doświadczeniu państwa rozwinięte mogą stać się „przekaźnikami” założeń

${ }^{52}$ At the level of the European institutions, this concept emerged with the adoption of the Maastricht Treaty. 
koncepcji, zabezpieczając i stabilizując sytuację w państwach sąsiadujących z UE. Przykładem takiej polityki bezpieczeństwa UE jest współpraca z państwami rozwijającymi się w basenie Morza Śródziemnego (BMŚ), które są odbiorcami zarówno środków, jak i wiedzy z tą koncepcją związanych. Wzajemna współpraca w ustanawianiu ram do jej stosowania sprzyja bezpieczeństwu wspólnego regionu, jakim jest BMŚ. Celem tak określonego obszaru badań jest analiza koncepcji rozwoju samopodtrzymującego się w kontekście formułowania założeń współczesnej europejskiej polityki bezpieczeństwa i ochrony porządku publicznego, biorąc pod uwagę uwarunkowania tej polityki wynikające z bliskiego sąsiedztwa społeczeństw odmiennych kulturowo.

Słowa kluczowe: rozwój samopodtrzymujący się, bezpieczeństwo publiczne, porządek publiczny, basen Morza Śródziemnego 